\title{
The Role of Tax Havens in the Tax Revenue Development and Its Reflection on the Public Revenues of the Developing Countries: An Empirical Study in Iraq (2004-2014)
}

\author{
Dr. Bushra Fadhil Khudhair Al-taie \\ Department of accounting, College of Administration and Economics, University of Baghdad, Iraq
}

Email: bushra_altaie@yahoo.com

\begin{abstract}
Hakeem Hammood Flayyih
Department of Banking and finance, College of Administration and Economics, University of Baghdad, Iraq Email: Hakeem.hmood@coadec.uobaghdad.edu.iq

Hassnain Raghib Talab

PHD candidate at school of business, Universiti Utara Malaysia, 06010UUM, Sintok, Malaysia Lecture, Accounting Department, College of Administration and Economics, Kufa University, Iraq Email: s95730@student.uum.edu.my

Noor Abbas Hussein

Master candidate at school of business, Universiti Utara Malaysia, 06010UUM, Sintok, Malaysia Email: s816532@student.uum.edu.my
\end{abstract}

\section{Doi:10.5901/mjss.2017.v8n2p289}

\section{Abstract}

\begin{abstract}
The aim of this study is to investigate the role of tax haven on tax revenue development and its reflection on public revenue in Iraq between 2004 and 2014. A review of tax haven literature revealed that there are different types of tax havens, categorizations, characteristics, effects of tax havens, socio-economic consequence and reaction to tax haven that requires analysis. An empirical analysis is done in the public revenue of Iraq from 2004 to 2014. Descriptive statistics and evidentiary are employed as the analysis techniques. It is revealed that the importance of structure analysis of public revenues is connected with tax haven because the basic foundation for the State budget. Also, the growth rates of tax revenue for the period beyond the year 2003 which saw the Iraq regime change and more open to the world and draws from a socialist economy to a market economy, as well as the effect of the tax was havens with the direct tax income withholding tax, as well as the impact of tax revenue in the Public State revenues. Withthe analytical nature of the study reported in this paper, there is still an opportunity for further work on larger populations to confirm the generalizability of the findings.
\end{abstract}

Keywords: Tax Haven, tax revenue, financial crisis, economic development, corporate governance

\section{Introduction}

The countries, states or territories in which at National level a low tax rate are levied or where tax are exempted are called Tax havens. Recently, around the globe issues concerning tax haven have moved from minority interest to an issue of global concern. Despite the fact that both industrialized and developing nations are hurt by tax havens yet the effect of the impacts are most remarkable in developing nations. According to Hines (2005), while most of the developing country are poor, and have a more significant demand consequently to secure most of their country tax base, the most part have weaker institution and less open door for authorizing the regulation and laws adopted by them accordingly. There is decrease in the tax system recently because of arrangements between developing Nation and tax havens regularly. Additionally, some impacts of tax havens have made some developing nations basically experienced similar events. Small nations having great political and ecological structure; that made tax haven to increase the huge amount of foreign reserve which in turn will help in their financial improvement with the proposition to charge lower tax so as to quicken their investment can be regarded as Tax havens nations. According to Hines (2005), it is reported that 0.8 per cent of the globe population is contributed by tax havens and at the same time records income of 2.3 per cent. 
Corporate Tax Rate (or Low Income) is known to be peculiar often. However, there are number of other components, for example, bank secrecy laws, that are similarly more vital. Tax haven is recognized as jurisdiction by economist where tax structure is deliberately established to exploit, and endeavor a global interest for chances to partake in tax avoidance. There is no definition agreed upon for tax haven, however the term "Tax Haven" implies; self-promotion as an offshore center generally $(G A O, 2008)$. The universally recognized definitions of Tax haven are used by the four key indicators recognized by OECD (1998). These definitions are:

- No or only Nominal Taxes: In order to maneuver high taxes in the country where they reside, tax is consistently at nil or nominal rate, or decide to give them self a spot to be utilized by non-citizen.

- Absence of Transparency: This is the dubious information exchange related to tax with foreign authority particularly bank secrecy operations that exists in an incredible consideration.

- Lack of commitment to exchange vital information with tax authorities of OECD member nations; and

- Absence of a requirement that makes an activityto be substantial ; that is transactions may be "booked" in the country with no or little real economic activity.

A jurisdiction can permit foreigners tax saving, whereby it can happen in three directions as proposed by tax havens. In the form of producing certain services and goods, activity can happen in the haven. This may further shift claims among jurisdictions and the haven can cover reality through secrecy in a way of concealing claims. Negative responses on the tax system are produced by each function (Kurdrle, 2008). Therefore, this study investigated the impact from historical perspective on developing economies and revealed the historical background of tax havens. The study found that improvement of the Euro advertised in the City of London ended up being the foremost force orchestrated by a coordinated foreign economy. The study further identified tax havens as a philosophy characterized as a little nation ordinarily below one million in population; and this is for the most part of the nations that agree mutually than developed countries. Apart from the characteristics discussed above, four different types of tax havens are also explained. Also the study explained the discouraging effects of tax payment and how Tax havens had negative and positive impacts on developing nations. Discussion on Socio-economic consequences of tax havens on developing world was also covered. The overall effect of tax havens as found out by the study is that: international cooperation mitigates the damaging effect of tax haven and the regulatory reactions to tax havens are finally elaborated.

\subsection{Historical Background of Tax Havens}

From the history of the permissibility of human creative ability, the rational amid tax haven has to do with tax resistance behaviors that date back to early civilization and expect structures. From the research, it is indeed critical in the Mediterranean zone to get exact origin of tax haven, but recommended in the history that the Second Century Before Christ perceived the first instance. The Island of Delos rehearsed a type of commerce which was free from custom duties and taxes, starting in $166 \mathrm{BC}$ and going on for almost each century from that point. The Island turned into a very important center of commerce and trade for ivory, textile, spices, wine, and wheat due to the geographical stance of the divers. In specific cities ("free towns") and also ports and fairs during the middle ages, there is an actualization of the same standard.

The rising of taxation in the 1960s is connected with the development of modern tax havens ordinarily. This is misleading to some extent because of two reasons. First, tax havens were created much earlier than the 1960s. Secondly, due to the ascent in taxation of advance industrial nations, which without a doubt occurred to control an establishment by England Bank in 1950s, and the emergence of the Euro market, or may be the foreign financial market in the late 1950s, the 1960s were particularly vital less. The Bank appears to have acknowledged the recommendation the exchanges attempted by UK relies upon benefit of a creditor and debtors who were automatically missing in the United Kingdom and were not to be formally seen in September 1957, having occurred in the United Kingdom for regulatory purposes despite the fact that the exchange was just ever recorded as occurred in London. Due to the understanding between the Bank of England and the commercial banks that is not directed by the Bank, the Euro market is an inter-bank or "wholesale" financial market. No other authority controls the market and thus it got to be viably unregulated or 'offshore', since the transaction occurs in London (Palan Ronen, 2009).

In order to gather with little extension of capitalism, the second was after the war during twentieth century, with the advent of the euro-dollar market in the 1950s, an incredible development occurred at the crucial moment of economic advancement as regards to the tax havens: the first was in the nineteenth century (Palan\&Chavagneux, 2007).The development of the financial Economy which was called offshore started in the late 1950s immediately after the establishment of the London-based Euro market. Because of the regulations, the biggest and giant among them refused 
to possess more than three percent; this is not an exemption whereby majority of United State Banks are among the US and the World's giant banks in the United State bank Assets(Sylla, 2002). By giving premise to the development of transnational's companies, huge amount of capital were collected outside the residential country of corporate owners and individual (Nairn, 1997). A group of financial specialist a large number of the microstates and dependent territories of OECD from a different continent oversaw the financial capital. Furthermore, Financial Action Task Force (FATF) and the G-20 countries deliberately regard themselves as tax havens; this means they regard themselves as semi-autonomous or autonomous territory providing a mix of different regulation on either low tax rate or even zero taxation on income and capital of non-residents.

Presently, at the extreme end of the world, there were palm trees and sun, also multimillionaires could get rich unwinding, and then the term tax haven brings out pictures related to tropical islands that can be easily found or spotted. In light of the certainty that the capital is moved forward for tax havens is growing in importance, this thought may be attractive and destructive (Mota and Lopes, 2009).

\subsection{Characteristics of Tax Haven}

Small countries having the population virtually and ordinarily below one million is one of the characteristics of tax haven (Altshuler et al. 2004). Moreover, tax havens are extremely well featured across the country with quality of governance measures that fuse measurements rule of law, effectiveness of government, political stability, accountability, and for defilement control. Practically, therewould be inadequate legislated tax havens. Dharmapala and Hines (2009) stated that, the inadequacy of the legislated nations where the world has a lot became Tax Haven. In additionto becoming tax haven over others is the possibility of returns over prominent, where international investment streams and the economic benefits that go as inseparable with are slanted with TaxAbatement in overall governed countries. The Tax diminishments over under-developing countries are the essential motivation behind better-governed nations (Desai et al. 2006).

Notably, tax havens are described as the nations that usually and unlikely to share information with different nations for the main reason of taxes, inadequate transparency, which alternatively have organizations that do not have considerable action in the jurisdiction as stated by Havens and Tax Competition initiative (Kudrle, 2008). In another vein, utilization is more general and perhaps more generous in characterization of tax havens as tax havens are small and operate with great legislated nations of low tax rates (Hines, 2007). Multinational companies were offered access to good infrastructure and offshore financing activities besides tax advantages by tax havens (Hines, 2005).

\subsection{Categorizations of Tax Havens}

Tax havens were grouped into four main parts viz:

1. Western Possessions: There is variation in the ultimate reason why nations may be named tax havens. Those nations frequently experience a kind of "mercantile reminiscence" and those type of government that have the ideology which should by all means have a huge cash deposit at their local bank while those governments begin a competitive tax race (Smith, 2005).

2. Sovereign Nation:In order to attract foreign capital inflow into their economy, most capitalist nations reduce taxes in their countries and negotiation of tax rates. The nations under this category hide the financial information from other countries and supranational agencies.

3. Countries Control by Cartels:Those nations have a propensity to be used to siphon fund as recommended by Killebrew and Bernal, (2010). However, the procedure through which this happens is exceptionally intricate and hard to standardize. These unique types of tax havens are obtained from currencies that are printed from non-official markets like: drugs, arms, other criminal activities in a simplified form; and instills that cash using the global financial system by the use of local deposits.

4. Emerging or Developing Economies:The tax havens are also seen as the economy benefitted from diverse rewards. While there are likewise helpful externalities for the entire population, the levies received have a tendency to be occupied by authority in the system of rents. Maurer (1997) understands that tax havens create a fact, local jobs and increase public revenue. There is a stronger tendency for financial systems of tax haven economies. Rikowski (2002) suggests that the tax haven alternative leads to positive consequences on local education. 


\section{Literature Review}

There is a sketch of the impacts of tax havens in developing nations as negative and positive impacts according to 2009 report on capital flight from poor countries by government commission. Those impacts are listed thus:

\subsection{The Negative Impacts of the Tax Havens}

The negative impacts of tax havens can be categorized into: damaging tax competition, effects of secrecy, financial crisis, inadequate allocation of investment, illegal transfer pricing and more unequal division of tax income or revenues. The effects are further clarified below:

1. Damaging Effects of Tax Haven:By offering mystery rules and invented domiciliary positions joined with "zero tax" regimes, tax havens have helped stimulating tax rivalry. Nevertheless, tax haven makes the national tax more delicate, where it impacts the level of taxation.Generally, this has proved to be limited than it is dreaded. The suggestion that national taxes law on mobile tax objects have to be harmonized and coordinated was prompted by the harming impacts of tax competition. Therefore, they are viewed as the most damaging impact of tax havens.

2. Insufficient Allocation of Investment: In order to increase the contribution to value creation where socioeconomic return will be the best, the investment would be made to acquire the highest return on tax-pre. Individual investors are not worried with the tax-pre form in this condition, but with the after-tax form. However, the more the tax system affects an effective loss of the economy, the more the distinction between socioeconomic returns and private. Consequently, tax havens will simply be changed by the investors behavior in order to build the differentiation between private returns and socio-economic. By providing them through the system of tax havens, the profitability of some investment in speculations would be updated.

3. Effects of Secrecy: Whentax havens become a through-pass area in which the investors' secrecy from the relevant tax administrations in their state of origin and from likely creditors is implied as confidential rules. However, where there is consequent low tax or zero return, the gained funds in this situation is profitable from the fees use of native legislatures and administrators by the international companies. Theactual cost of committing the economic dilemma is the influence of these rules on different nations as diminishing in the light of the fact that both the criminal attitude and its returns can be disguised.

4. Tax Havens and Financial Crisis: The new sorts monetary mechanisms and derivatives controls the financial crisis in which money deposited are located in confidential authorities. Inorder to realize the threat profile that they were getting, the utilization of intricate new monetary mechanisms made it troublesome for individual investors. Financial crisis has incited the breakdown of banking sectors as rock-strong taking the case of Carnegie and Lehman Brothers into consideration. These insolvencies depend on the banks as they have no any basic trust in each other's money/financial related quality/strength. Similarly,in the global and financial market, they grow the risk quality on monetary exchanges.

5. Illegal Transfer Pricing: This is the methods that are available for multinational Industries to move profits from the higher-tax nations to a lower-tax nation.

\subsection{The Positive Effects of Tax Havens}

Tax haven could have positive effect on economic growth in two nations: The nations that are not tax havens, and; those nations that are tax havens. The study concentrates on those impacts influencing the prosperity of tax haven. These include:

i. Beneficial Tax Complex:There is tendency for political system to set the level of taxation excessively high. This conceptualized idea is derived from the prospect that elected legislators; they are not mainly worried to serve the needs of the voter, rather they have personal interest in raising the abnormal high stage taxes (Brennan \& Buchanan, 1980). However, such personal notions may probably be the longing power that can be fortified by an extensive government sectors. The tax havens discipline legislators have the goal the idea that does not increase the taxes above normal levels and desirable for the voters by considering all things.

ii. Increased Investment in High-Tax Countries:In nations with high-tax, tax havens will help to contribute to increase in financial activity; in this way, they don't swarm out investment there. According to Desai, et al. (2006), tax havens can significantly help to influence the level of investment if the financiers can be able to move taxable incomes from a high-tax nation to a tax haven. This willmake further striking for more investment 
and extend the effective return rate on investment in high-tax nations. However, the utilization of tax havens can be well sourced from tax credits which should similarly decrease the successful tax rate on interest in high-tax tally or count.

iii. Economic Development in the Tax Havens: These are institutional bodies which ensure for the manner of financial transactions that can be imperative and the wellbeing of investment. Dhammika and Hines (2006) stated that Tax havens are to be well organized while the oppositionsare ready to take over capital hones essentially for institutional advantage and great governmental issues. The rivalry opposition over capital among tax havens enhances the developmental solutions since institutional excellence is a foremost element for economic development (Hines, 2004).

\subsection{Draw-back Effects onTax Payments}

Capital trip, both financial problems and levies economic costs are inspired by tax havens through less investment, low economic growth and increasing rate of unemployment. As the tax status generates a solid motivation to household resource holders in developing nations to keep their assets offshore, capital flight may be caused by financial crises. To rescue their wealth from potential cash depreciation and from paying taxes, there must be a Continuous undertaking of this mysterious basis which empowers them (John, 2011).Both their capital investment and income tax that would then flow from the capital being invested into local economy will be misplaced by this unavoidable result of this large break of capital transferring towards the north as a rising nations.By providing pointless tax incentives, they additionally allow a great opportunity of tax avoidance in the local perspective from regularly from activities of the shadow economy, tax avoidance on cross-border trade and from the pressure to vie capital investment. Annually, these tax incomes are forgone, thus costing developing nations roughly $\$ 385$ Billion (Cobham, 2005).

In the following different techniques, the study posits there is huge discharging of the local monetary resources of numerous developing nations, which weakens manageability.

- In order to substitute other taxes or indirect taxes with a resulting reverting effect on riches and income dispersion, there must be a reduction in tax income from the rich and high-income earners for quality governments.

- Dropping tax incomes of power reductions in learning, transport and other infrastructures. Also by decreasing investment and abating development in the public investment.

- Tax avoidancemakes destructive economic misrepresentation and undermines the reliability of tax administration that punishes the individuals who defy the rule and advantaged individuals who do not follow principles.

- Tax avoidance weakens the respectability of government based on democracy and public appreciations for the guidelines of low.

\subsection{Tax Haven Socio-economic Consequences on the Developing Countries}

Tax haven is an area where low tax rates are imposed on corporate responsibilities which engage with foreign investors as characterized in the literature above. Vicinity tax haven countries harm different countries particularly developing nations are the observations among approached creators and academicians. According to Torvik, (2009) and Schjeldrup (2011), the accompanying reasons were distinguished into four as follows:

1. It pulls outside the payment venture from theeconomies and therefore strips them of tax revenues;

2. It heightens tax competitive conducts;

3. It activatesthe maintenance of less quality foundations in developing nations by increasing the gainfulness of unlawful and inefficient exercises; and

4. In developing nations, offshore riches possessions by high total assets people may further expand salary imbalance and undermine more extensive tax spirit in the society of tax agreeability.

Furthermore, by a percentage of the biggest world multinational corporations working in developing countries, the Guardian has realized more news far reaching utilization of tax havens. It is stated that the poorest nations lose triple times more cash to havens per year than what they got in help according to Richard Miller, (2013) in his study titled: "Tax Haven are entrenching poverty in developing countries". Due to Tax evasions which hit the poorest countries in the hardest ways, the investigation affirmed that these tax havens can very frequently give vehicles avoidance of tax. Tax haven confidentially adopted a policy to divert investigations from an extent of unaccountable transactions in developing 
countries. Two mining deals including FTSE 100 multinationals brought out through organizations in the English Virgin Islands, Panama and Gibraltar were highlighted by the most recent African Progress Panel led by United Nations Secretary General Kofi Annan. The case of the board have disallowed the democratic Republic of Congo of predicted $\$ 1.36$ billion, which is almost double of the country's education and health budgets joined together.

Tax haven proposes a harbor for wealthy and benefit directed from round the globe from desert Caribbean Islands to Major monetary centers. For unlawful tax evaders and repudiating growth economies that the general public revenues needed for medical and education centers, and clean water and dealing streets, tax havens offer legitimate equipment to tax evaders, and assurance. As indicated by the organization of economic co-operation and development, the figures are shocking as developing nations lose 3 times more cash to tax haven annually than the amount they get for aid.Generally, there is an insignificant motivating force that positioned not to place advantages and resource in tax havens organizations, or to reveal these advantages and resources, unless government themselves stop secrecy and abusive tax regimes that tax havens provide. There is an extraordinary mix of financial and political weight, obligation and purview over issue as spoken by G8 nations at June. In 5 of the world's tax havens, the United Kingdom is answerable for one over other single nation within the world. In order to uncover the money assets and their taxpayers hold offshore,the United Kingdom and alternative wealthy nations have late begun to push their tax havens. These arrangements to date forgot making nations to neglect tax haven.

\subsection{Reactions to Tax Havens}

To be specific, there are essentially two kind of administrative responses namely: multilateral and unilateral.

\subsubsection{Unilateral Measures}

These measures propose the engagement of a lone state. This is useful in a moderate manner that is less intricate than the execution of multilateral measures. In the expense of sanctuaries and tailing a percentage of the writing as examined by Murphy (2008) and Ginevicius and Tvaronaviciene (2010), the most imperative one-sided measures are according to the following:

i. Lifting of Banking Secrecy: In spite of the negligence, this is a measure of noteworthy leap forward regarding straightforwardness in order to explain the more extensive methodical irregularities that record an incredible aberration in the appropriation of riches.

ii. Fiscal Transparency of Outland Social Orders: In order to the show of capacity to report and supply records for any business exchange, drove by a honest to goodness component enlisted abroad, fiscal straightforwardness from organizations alludes (Dumludag, 2011). This measure is proposed to assess the non-returned benefits of organizations that are built up in duty sanctuary.

iii. Adjustment of Transfer Prices: To conform the costs in exchange between elements that have unprecedented relations with each other when those costs differ from expected costs in states of full rivalry, then this alludes to a monetary power's ability to review its VAT base. Through the examination of valuing for exchange of the same sort between non-related elements, the full rivalry cost is determined.

iv. Prevalence of Substance over Structure: This alludes to the structure of a salary creating movement than its structure or to the procurement of legitimate importance and heavier weight to the piece of a monetary or other sort of action that are in representation lawfully contracted.

v. Reversed Onus of Proof: Since it would be the citizen's obligation to show that no assessment evasion plan was sought after; this measure could conceivably yield helpful results. A legitimate principle expressing that the informer is not in charge of giving activities of the faulted is called turned around onus of verification.

vi. Declaration Necessity: This empowers citizens to maintain any entireties paid occasionally or because of outside elements to the duty powers. If the switched onus of confirmation is guarded, a commitment will be declared well. It ought to be noted that in the light of what has now been noted above with regards to the late announcement law.

\subsubsection{Multilateral Measures}

These suggest the collaboration of various gatherings where their usage is intricate and the inclusion of different states. Multilateral measures incorporate the following measures:

i. Tax Harmonization: The demonstration of hoping to alter prompt tax assessment rates more about in all legal 
space is incorporated by Tax harmonization with the point of suspecting capital flight to seaward monetary focuses (Torvik, 2009).

ii. Request for Information: In order to gain more straightforwardness, this was the measure that the OECD asked from the distinctive duty shelters; this fundamental includes giving or being willing to give available data. When asked for concerning monetary inquiries that are identified with national premiums or the lifting bank mystery for money related reason, the all-around concurred data of trade standards created by OECD and supported by UN and the G20 foresee the complete trade of data.

iii. Control of Interbank Electronic Messaging: This is societal-oriented for Worldwide Interbank Financial Telecommunication (SWIFT Worldwide) whose point is to support the programmed handling of electronically imparted messages between banks. Therefore, in order to recognize every operation fusing trade with seaward budgetary focuses which would be subjected to examination at whatever point extortion or duty evasion when suspected, there should be a Supervisory Authority that could control and channel all these messages.

iv. G20 and the European Union:A standard that is affirmed by the $G 20$ and United Nations Expert Committee on International Co-operation in Fiscal Matters is built by The Global Forum on Taxation (GFT) guided by the work of OECD's Committee on Fiscal Affairs. Thus, this serves as a lion share in portion of respective Fiscal Agreements and as a comprehensively settled data of trade standard (Palan\&Chavagneux, 2011).

\section{Research Methodology}

This section is divided into two parts: data collection and data analysis. It explains how the data was obtained and consequently analyzed. This empirical study with significant large part of theoretical reviews employed the use of secondary data which provide records and accounts in a workable format. The data were deducted from public and tax revenue with their respective overall growth rate within the year 2004-2014. The method used was based largely on deductive method and the use of secondary data was done after the collection of the data from various aforementioned databases in Iraq. The data was then analyzed through multiple regressions.

\subsection{Data Collection}

The study adopts the case study approach to investigate the role of tax haven on tax revenue development and its reflection on public revenue in Iraq between 2004 and 2014. The approach to the research is a pattern of research conducted with activities ranging from identification of problem, literature review, and specification of research purpose, collection of data, analysis and interpretation and then reporting (John, 2008). These steps are followed in their strict terms so as to achieve the research objectives. Since the purpose of this study is to investigate the impacts and effects with a view of analyzing and predicting the nature using statistical computations, a quantitative approach is appropriate for this study (Zikmundet al., 2010). This study represents a formal research to empirically investigate the influence of tax haven on tax revenue developmentin Iraq between 2004 and 2014. Due to the highlighted objectives of this study, it is exclusively a quantitative research with methods for the realization of the objectives.

The tools used as analysis are descriptive statistics and evidentiary, as tax havens directly realigned withholding tax which is a variable and it was selected by the researcher who studies the independent variable exclusively, and the accompanying independent variable, of the tax revenue, which is at the same time, the mediator variable, which affects the dependent variable is the Public State revenues. The first hypothesis: there intangible relationship statistically significant between tax Havens and tax revenue. The second hypothesis: there intangible relationship statistically significant between tax revenue and Public revenue. The table shows the results of regression coefficient of the relationship between variables.

This is the importance of the quantitative type exploratory study done by this study. The significance of a study being an exploratory type is that it helps in understanding the situation being studied more comprehensively and accurately. In the course of employing the descriptive research design of this study, the following are to be achieved accordingly:

i. Definition of the problem of the domain and consequent formulation of the hypotheses to be investigated;

ii. Identification of the concepts and challenges in the research techniques;

iii. Presentation of belief concepts and approach that can implement effective data interpretation, especially in multivariate data analysis;

iv. Exploring quantitative data to reveal unknown relationship between the variables studied. 
The issues educed in this study are addressed by the application of the exploratory research study as listed above.

\subsection{Data Analysis}

Generally, there are two main approaches to research: qualitative and quantitative. The third approach, commonly referred to as mixed approach is the combination of quantitative and qualitative, and it is currently getting more attention (Creswell, 2009). This study employs the quantitative method to identify the impact of all the elicited tax haven core elements on developing countries, and the role of unilateral and multilateral measures and policy. Therefore, study is much of regression, studying the effect of one variable on the other. Quantitative design gives the befitting opportunity to effectively test the research hypotheses, and practically solve the pointed research problem. And also, taking into consideration of the methodology employed by past studies, especially their statistical analysis process, this study makes a methodological contribution.

This study is using a survey research as its quantitative approach of study. Thus, secondary data are used and suitably appropriate as to gather information. All the variables to be investigated in this study are a continuous variable. Also, due to the suitability of quantitative research data to be numeric, deducting data from 2004 to 2014 from the relevant revenue data of Iraqi public firms serves as the most reliable approach of data collection that will fit in with these features. This is undoubtedly justified because this study is interested in capturing the sequence and draw back effect of tax haven at each specific year. It means the information expected to be deducted from the Iraqi public revenue can best be derived from the company's reflection of the work environment reality and its differences.

In summary, the public revenues and rate of growth for the period of 2004 to 2014 is generated. From each year, the tax revenue is calculated. While the percentage of overall revenue is derived from each year, the growth rate of tax revenue was also derived. From the annual salaries got from each year, the direct withholding taxes are calculated. Therefore, from $\mathrm{h}$ annual wages and withholding taxes, the direct withholding growth rate of tax and payroll growth rate are calculated in percentage. From the above deductions, it is easy and convenient to know the values of correlation and regression between the research variables. The following section reveals the values of correlation and regression of both dependent and independent variables of this study.

\section{Analysis and Discussion}

In different nations, tackling the issue of tax avoidance and evasion with the use of tax havens has attracted a significant number of proposals. Actions moved by the G-20 industrialized nations and the Organization for Economic Cooperation and Development (OECD) addressed these issues (OECD, 2004). Many of legislative proposals to attend to corporate tax avoidance and individual tax evasion are being advanced. Mitchell and Daniel (2006) stated that multinational firms can shift profits artificially from high-tax to low tax jurisdictions by applying different techniques like moving debt to hightax jurisdiction. There is tax levied on the income of foreign subsidiaries except for some specific passive income that are deferred till the income is remitted into U.S account as a dividend; this income can then avoid present U.S taxes indefinitely and some other developing nations (OECD, 2011). Passive income taxation has been significantly reduced through the application of hybrid entities that are adjusted in respective jurisdiction differently (Eggert, et al. 2002). There was a great expansion due to the use of hybrid system by new regulation introduced in the late 1990s out of unexpected implications of foreign firms. Additionally, earning from income that is taxed can be often protected from foreign tax credits (Desai et al. 2006a).

In a year, there can be losses that may approach or exceed $\$ 100$ billion a recent as suggested by recent estimates (Louie, et al. 2008). Additionally, individual can evade tax by establishing a shell corporation and trusts haven nations in abroad to convey funds into foreign jurisdiction as the interest paid to receiver is not taxed. No third party report of income as in the case of ordinary passive income that are earned domestically (Huizinga et al. 2003). Thus, the Internal Revenue Service (IRS) depends on Qualified Intermediaries (QIs).

\subsection{Empirical Analysis}

Importance of the structure of the Public revenue analysis comes because it is the main pillar of the Public budget of the state, as it is noted that it was (in 1598) almost one billion dinars for the year 2003 to jump to the (3298) billion dinars, almost, and continued to increase until the year 2008 as it has achieved $(80,641)$ billion Iraqi dinars, but fell in 2009 to $(55$ 243) billion dinars as a result of the financial crisis, the vernacular, has rebounded over again until the year 2013 as a result of falling oil prices, because the Iraqi economy is a yield economy depends on oil in Public in the face of public 
expenditures, and notes that the ratios It is noted that revenue growth rates have declined for 2013 and 2014. So I had to focus on tax revenues that are in continuous increase to meet the shortfall in income, table (1) Public State revenues and tax revenue growth rate for the period (2003-2004). Annual salary represents a significant penalty of operating expenses, ranging in Iraqi State staff to nearly 4 million employees, so that one third of the operating budget is salaries and wages offered to employees, forgiveness is granted on those salaries and wages taking into account social situation of citizens which may affect the size of the tax revenue of the withholding tax levied on direct those salaries. Table (2) shows the annual wages and withholding tax.

\subsection{Discussion}

The first hypothesis test:

And through a table (3) the correlation coefficient of relationship between moral relationship statistically significant between tax Havens (Tax Havens) and tax revenue (Tax revenue) (0.71) moral significance level (0.05), this strong correlation and $d$ positive and moral, while the value of (F) calculated for the template (9.5), the largest value (F) of table (4.19) significance level (0.05), and therefore accept the hypothesis, this means having a statistically significant effect of tax Havens abstract level (5\%) Confidence limits (95\%) In tax revenue It is clear from the coefficient of determination $\left(R^{2}=\right.$ 0.51) that tax Havens interpreted (51\%) of changes in tax revenue.

The proportion is $(49 \%)$ due to the contribution of the other variables included in the regression model. As evidenced by the coefficient marginal propensity to deep gradient angle $(\beta=13.5)$ that any increase in the level of tax Havens one unit would increase tax revenue by level (135\%). P Value indicates which was worth $(0.013)$ to spirits parameter, regression coefficient estimation result confirms, were moral statistically being less moral level (0.05), indicating the effect of tax revenue tax Havens. The above results would be to accept the first hypothesis.

The second hypothesis test:

Through the table (3) correlation coefficient of relationship between moral relationship statistically significant between tax revenue and Public revenue reached $(0.08)$ moral significance level $(0.05)$, this link is weak but positive , while the value of $(F)$ calculated for the template (0.05), which is less than the value $(F)$ of table (4.19) significance level $(0.05)$ and accordingly reject the hypothesis, that means there is no statistically significant effect of tax revenue at the abstract level (5\%), confidence limits (95\%) in the overall revenue.

It is clear from the coefficient of determination $\left(R^{2}=0.007\right)$ that tax revenue explain $(70 \%)$ Of changes in overall revenue, either of (99.3\%) Due to the contribution of the other variables included in the regression model. As evidenced by the coefficient marginal propensity to deep gradient angle $(\beta=3.73)$ that any increase in the level of tax revenue in one unit will increase the level of public revenues (373) \%. P Value indicates which was worth (0.82) to form moral teacher, was greater than the moral level (0.05), indicating the lack of effect of tax revenue on Public revenue. The above results the second hypothesis would be rejected.

In conclusion, the importance of structure analysis of public revenues because the basic foundation for the State budget, researchers study the growth rates of tax revenue for the period beyond the year 2003 which saw the Iraq regime change and more open to the world and draws from a socialist economy to a market economy, as well as the effect of the tax was Havens with direct tax income withholding tax, as well as the impact of tax revenue in the Public State revenues . It has been concluded that tax revenues are affected by grace given according to tax law, the patron social conditions and the suffering citizens of social conditions, and that the Iraqi economy is an economy of REl, mainly depends on oil revenues are not affected by income from tax. So I have to concentrate on the aspects that develop the role of tax revenue increase public revenue under the circumstances that you may experience fluctuations in global oil prices.

\section{Conclusion and Recommendation}

\subsection{Conclusion}

As a result of low-tax jurisdiction which gives chance to investors from tax avoidance, this study found out that tax haven has now moved across the world interest from minority concern. Where various indicators recommend that tax havens help keeping up an endless loop in emerging countries, its presence is presuming most at times to have significant effect on public institutions in rich countries. This allows weak institutional limit and encourages illicit capital flight.The development of Euro market in the city of London ended up leading the force behind an integrated offshore economy that focuses on London. These include odds and ends of the British Empire that lead to deteriorations of emerging countries economy. The negative impacts contributed more to the collapse of developing nation's economy with little or no positive 
impact. This has led to inadequate allocation of investment, undermining the work of tax system and reduction in tax base in developing countries. The developing nation's resource allocation was reduced and the institutional qualities and growth has been damaged as a result of tax havens as revealed by the history.

In conclusion, positive impact of tax havens is generally bound to rich countries' jurisdiction alone, while the developing countries are being affected by the negative ones. Additionally, the capital flight commissioned from emerging countries cannot see the positive influence of tax havens which are in any capacity enough to commensurate the harmful effect highlighted.

\subsection{Recommendation}

All provisions available to address shift of profit by Multinational involve change of tax law such as: limiting or repealing deferral and limiting the ability of the foreign tax to offset income, addressing formula apportionment and even the checkthe-box. Change in anti-abuse provisions and law have also been employed in broader tax reform proposals. Provisions to increase enforcement includes shifting the burden of proof to the taxpayer, increased resources and increased penalties while provisions to address the individual evasion include increase in information report.

\section{References}

Altshuler, Rosanne and Harry Grubert. "Taxpayer Responses to Competitive Tax Policies and Tax Policy Responses to Competitive Taxpayers: Recent Evidence."Tax Notes International 34, no. 13, 2004, 1346-1362.

Blanco, L., and Rogers, C. "Competition between Tax Havens: Does Proximity Matter?" Pepperdine University, School of Public Policy Working Papers, 23, (2011) pp 11-20.

Christensen, J. "The Looting Continues: Tax Havens and Corruption". Critical Perspectives on International Business, 7(2), (2011),177196.

Commission on Capital Flight from Developing Countries.."Tax Havens and Development". Report from the Commission on Capital Flight from Poor Countries(2009).

Creswell, John W. "Research Design: Qualitative, Quantitative, and Mixed Methods Approaches". 3rd Edition. Los Angeles: Sage Publications, Inc., 2009.

Desai, M. A., Foley, C.F., and Hines, J.R. "The Demand for Tax Haven Operations."Journal of Public Economics, 90(3), (2006),513-531.

Desai, Mihir A., C. Fritz Foley and James R. Hines. "Do Tax Havens Divert Economic Activity?" Economic Letters 90, February 2006a, 219-224.

Desai, Mihir A., C. Fritz Foley and James R. Hines. "Taxation and Multinational Activity: New Evidence, New Interpretations." Survey of Current Business 86, no. 2, February 2006, 16-22.

Dharmapala, D.A., andHines, J.R. "Which Countries Become Tax Havens?" Journal of Public Economics 93(2009), 1058-1068.

Eggert, Wolfgang, and Martin Kolmar. "Residence-Based Capital Taxation in a Small Open Economy: Why Information is Voluntarily Exchanged and Why it is Not." International Tax and Public Finance, 9(4), 2002: 465-482.

Huizinga, Harry, and Soeren Bo Nielsen. "Withholding Taxes or Information Exchange: the Taxation of International Interest Flows." Journal of Public Economics, 87 (2003): 39-72.

John, A., and Ngoasong, L.. "Budgetary and Management Control Process in a Manufacturing : Case of Guinness Nigerian PLC" (2008).

Kudrle, R. T. and Eden, L. "The Campaign against Tax Haven: Will it last? Will it Work?" Journal of Business and Finance 37(2004).

Kudrle, R.T. "The OECD's Harmful Tax Competition Initiative and the Tax Havens: From Bombshell to Damp Squib". Journal of Global Economy, 8(2008). 1524-5867.

Louie, Henry J., and Donald J. Rousslang."Host-Country Governance, Tax Treaties and U.S. Direct Investment Abroad." International Tax and Public Finance, 15(3), 2008: 256-273.

Miller, R.. "Tax Havens are Entrenching Poverty in Developing Countries"(2013).

Mitchell, Daniel J. "The Moral Case for Tax Havens" Occasional Paper 24, LiberalesInstitut, 2006.

OECD, Center for Tax Policy Administration. The OECD's Project on Harmful Tax Policies The 2004 Progress Report, Paris, France: OECD, 2004.

OECD. "The Era of Bank Secrecy is Over." The G20/OECD process is delivering results, 2011 available online at http: // www. oecd. org/ dataoecd/ 54/60/ 48996146. pdf.

Palan, R., Murphy, R., and Chavagneux, C. "Tax Havens: How Globalization Really Works". Journal of Economic Geography 11(2011), 753-756.

Raposo, A.M., and Mourao, P.R.."Tax Havens or Tax Hell?A Discussion of the Historical Roots and Present Consequences of Tax Havens."Journal of Financial Theory and Practice, 37(2013), 311-330.

Tobin, G., and Walsh, K.. "What Makes a Country a Tax Haven? An Assessment of International Standards Shows Why Ireland is Not a Tax Haven". The Economic and Social Review, 44((2013)), 401-424.

Weiner, J.M. andAult, H.J. "The OECD'S Report on Harmful Tax Competition". National Tax Journal, 5(1998), 601-608.

Zikmund, W. G., Babin, B. J., Carr, J. C., and Griffin, M.."Business research methods" (8th Ed.). Canada: Nelson Education, Lt. (2010) 


\section{Apendix}

Table I: Public Revenues and the Rate of Growth for the Period (2003-2014)

\begin{tabular}{ccccc}
\hline The growth rate of tax revenue\% & Tax revenue & Overall revenues\% growth rate & Public Revenues & years \\
\hline---- & ----- & - & 15985227 & $\mathbf{2 0 0 3}$ \\
--- & 73613 & 106.2 & 32988850 & 2004 \\
1.50 & 184175 & 22.5 & 40435740 & $\mathbf{2 0 0 5}$ \\
0.67 & 307943 & 21.3 & 49055545 & 2006 \\
0.43 & 440733 & 12.0 & 54964850 & 2007 \\
0.20 & 527524 & 46.7 & 80641041 & 2008 \\
0.15 & 605921 & $31.4-$ & 55243527 & 2009 \\
0.19 & 723342 & 27.0 & 70178223 & 2010 \\
0.21 & 874341 & 55.0 & 108807390 & 2011 \\
0.31 & 1148042 & 9.8 & 119466403 & 2012 \\
0.18 & 1360371 & $4.7-$ & 113767000 & 2013 \\
0.08 & 1465261 & $7.0-$ & 105400000 & $\mathbf{2 0 1 4}$ \\
\hline
\end{tabular}

Table II: The Annual Wages and Withholding Tax.

\begin{tabular}{ccccc}
\hline Direct withholding tax growth rate\% & Direct withholding tax & \%Payroll growth rate & Annual salaries & years \\
\hline---- & --- & --- & 1633987 & 2003 \\
--- & 5808 & 5.43 & 10507142 & 2004 \\
13.41 & 83695 & -0.02 & 10277047 & 2005 \\
0.98 & 165628 & 0.22 & 12498153 & 2006 \\
0.27 & 210935 & 0.05 & 13102782 & 2007 \\
-0.14 & 180354 & 0.71 & 22425732 & 2008 \\
-0.47 & 96251 & -0.17 & 18529907 & 2009 \\
-0.24 & 73046 & 0.26 & 23378067 & 2010 \\
1.22 & 162043 & 0.12 & 26252556 & 2011 \\
0.67 & 271070 & 0.15 & 30124930 & 2012 \\
0.15 & 311851 & 0.18 & 35624333 & 2013 \\
0.24 & 387422 & -0.13 & 31116923 & 2014 \\
\hline
\end{tabular}

Table III: Values of Correlation and Regression between Research Variables

\begin{tabular}{lcccccc}
\hline Independent variable & $\boldsymbol{\beta}$ & $\mathbf{R}^{\mathbf{2}}$ & $\mathbf{P}$ value & $\mathbf{F}$ & Correlation & dependent variable \\
\hline Tax Havens & 13.5 & 0.51 & 0.013 & 9.5 & 0.71 & Tax revenue \\
Tax revenue & 3.73 & 0.007 & 0.82 & 0.05 & 0.08 & Public Revenues \\
\hline
\end{tabular}


ISSN 2039-2117 (online)

ISSN 2039-9340 (print)
Mediterranean Journal of Social Sciences MCSER Publishing, Rome-Italy
Vol 8 No 2

March 2017 